145 理境における心理物理量としての光放射の数量化の問题点:

音測定では解決娍たが, 光放射湖定では未解決の事項は何か?

佐藤子（浜松医科大学医学部心理学科）

音瀬定（僡感補正した音压レベル(SPL)で の测定)では解決ずみで光淜定（視感補正し た輝度，照度での测定)ではまだ問阙にもさ れていないことが，基本的重要事項に関して 2 項目ある。時間を考虑にいれた繥量（强度 ×持繶時間) 計量の計測体系と，個人差を考 虑した計洞単位である。

1 : 音エネルギー陚量計算法と計算機能付路 音計交通音，生活䮴音なと日常現境内 の音は，强度が一定しないレベル变動音であ る. 一定强度の音が持続する(定常音)こと は稀である。人間への音の影望は音エネルギ 一総量に対応するので，現在各国で用いられ ている各種の政音評洒法は一定時間内給エネ ルギ一量か，一定時間内エネルギ一平均値に 大别される。この2大方法に音スペクトル， 奥拏性，一定時間内音强度分布，その他を加 味し，さらに航空機䮩音用，重撃音の反復回 数，道路鰞音用なども考虐して各国各種の方 法が生れた。しかし，類似の镅洒法が次々に 提案され，あまりに被稚になったので国際標 準化機楎（ISO）が比較的簡単な方法を採用す るよう针めたのが，等洒駔音レベル（Leq）で 計量し，それに简音，音スペクトルの性筫， 継続時間なとによる補正も加える方式である。

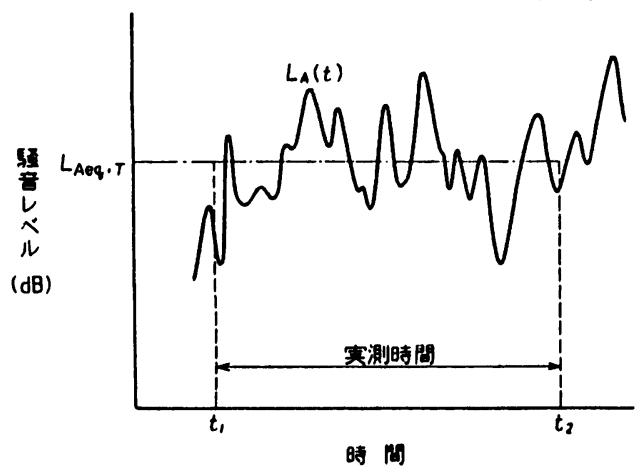

Le $q=$

$1010 \mathrm{~g}, 01 / \mathrm{t}=-\mathrm{t}, \int_{t_{1}}^{t_{2}} 10 \mathrm{~L}=(\mathrm{t}) / 10 \mathrm{dt}[\mathrm{dB}(\mathrm{A})]$

例えば航空機鉄道蜸音には0.5秒间隔で泪 定し，10秒間，24時間などで正规化（実効感

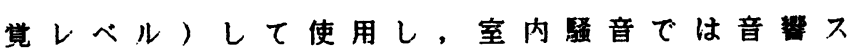

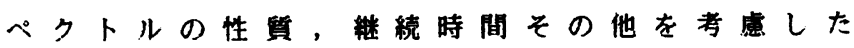
補正を加え（評洒疆音レベル）て使用してい る、レeqその他の計算のために総計算能付
跭音計も既に 100 数年前に日本国内で㱔造さ れている。この計算機能にはL5,L95,L50， Lmdnな゙の算出も含まれている.これらの計 量値ま音のレベル変趿を考慮して考案された。

2 : 音の個人物差

音压レペル $(S P L) \quad(d B)$ $2010 \mathrm{~g} 10 \mathrm{P} / \mathrm{P}$ 。の $\mathrm{P}$ 。は，基準音压として平 均的な成人の $1000 \mathrm{~Hz}$ 最小可殭值に相当する とされる $20 \mu \mathrm{Pa}$ と定められている。この基葏 P。のかわりに各個人の $1000 \mathrm{~Hz}$ 最小可㯖值を 実测して用いる（音の感賞レベル）と腎力の 個人差が大きい場合にも，計澌值がすべての 人に同じ大きさにきこえているので，便利で ある、SPLのままでは，図1 1 からわかるよう に,おなじ50dBの音でも耳の神経生理的心理 物理的原因て，小さく聞こえる人と大きいと 閐こえる人とがいるからである。この個人差 を図1に示した。感賞いき值の高低と刺激强 贵に対する度答筑囲との関係から感賞の個人
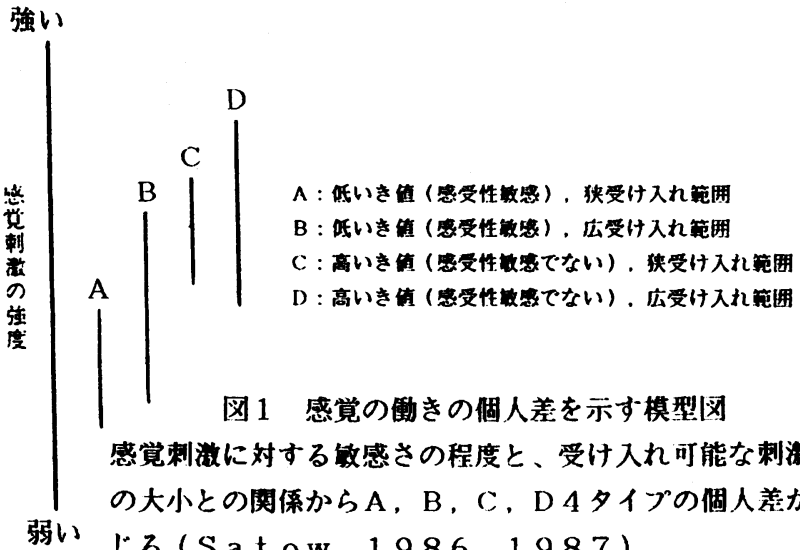

図 1 感賞の働きの個人差を示す模型龱 感覚刺激に対する败感さの程度と、受け入れ可能な刺激量 の大小との関係から $\mathrm{A} ， \mathrm{~B} ， \mathrm{C} ， \mathrm{D} 4$ タイプの個人差が生 じる ( S a t ow, $1986 、 1987$ )

差を説明している。音の感賞レベルは各人の 下限值で基淮化した個人物差である。感賞レ ベルで50dBの音は各人に同じ大きさに閏こえ ているはずである。この関係は従来のいき值 测定方法で測定できる。

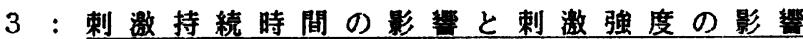

人間への音の影掣は音エネルギ一総量に対 応するが，これは䁣賞に限らすすべての感堂 に共通する。感賞刺激の影慗の程度には刺激 
强度で計量できる側面と，総量でなければ計 量できない側面がある。熱刺激でいえば前者 は高温火偒で，弱く薄い皮成ほと時に火賃 する。後者は低温火傷て，始めは心地上く感 じられたこたつゃ湯タンポの長時間使用が原 因であるが，皮属が厚くても長時間なら発生

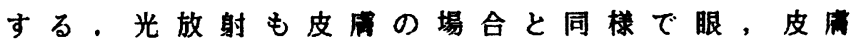
への影䉕にかぎす成長発育，ホルモン活動 状況など全身的に長時間の影睎はある。図 2 は刺激持続時間を加味した刺激受入れ可能総 量と刺激强度応答（図1 1 の下限值，上限值， 下限上限箐囲\{棒の長さ\}のどれをもちいて もよい) の関係から個人差を説明する模型図 である。図 2 に実测值をいれる際，光放射の 計量には音のよeqに相当する計測が制定され ていないので，現状では（輝度 $\times$ 時間）しか ない, 感受性敏感、低いき值

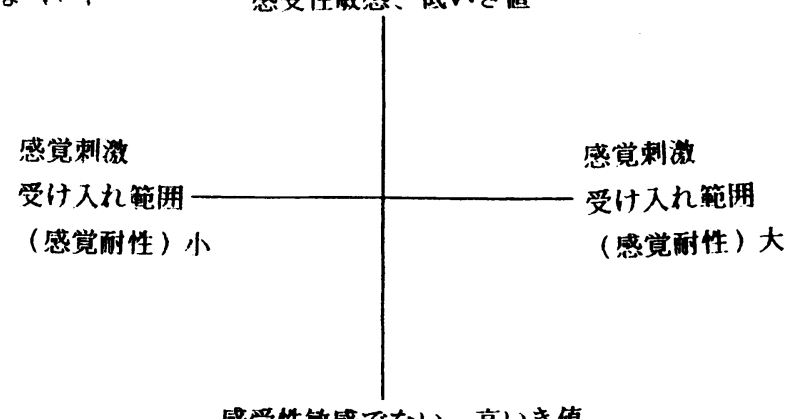

この园は先の龱1のA，B，C，D4タイプを別の形式で あらわしたものである。いき值の高低を样軸に、受け入れ 可能範囲を横軸にすると、個人はこの4采限の中のどこか に位宣つけられる。

\section{4 ：光放射の計量体系に取入れるべき事項}

4 - 1 輝度の時間変動を加味した総量計測 法

光も微視的には音同様にレベル変動してい るが，日常の計测オーダーでは持続光が多い ので，現在の测光体系には時間要因は加味さ れていない.光の人間への影䈏を取り扱うに は時間要因を加味した計量方法を制定する必 要がある。現在，農業牧畜分野で使用されて いるルクスアワーと写真技術分野で使用され ているミリワットでは，光强度は一定または 季節単位の長時間で一定で算出される。音測 定で実行されているような短時間変動は加味 されていない，視環境設計のよりところとさ れる推掊照度基準にも時間要因は短時間長時
間ともに加味されていない。これが，実蝴で は望ましいとされた照明条件で設計された醋 場が，その後の現地調査では望ましくないと される場合がしばしばあることの原因である。 $4-2$ 光尺度の複数化

個人の物差と個人差の物差：輝度照度に は音の感覚レベルに相当する個人物差がない。 明るさの感賞レベルがあれば，照度8001×が 各個人でどの程度異なって感じられているか を，数量的に示すことができる。さらに感莧 レベルと踣度照度上の数值の関係から，個人 を明るさ尺度上に相対的に位面づけることが でき机ば，視環境設計の际の個人差の取り扱 いに有効であろう。

䙉数次元測定の組合せ尺度：照明光の 見えかたには明るさ以外にまふしさ，見やす さがある。これらに対する感賞は 1 次元の測 定ではあらわしきれない，䙓数次元の洞定の 租合せと，それぞれの次元での心理量を道切 に心理物理量としさらにそれを物理量にする ための操作が必要である。

引用文裁

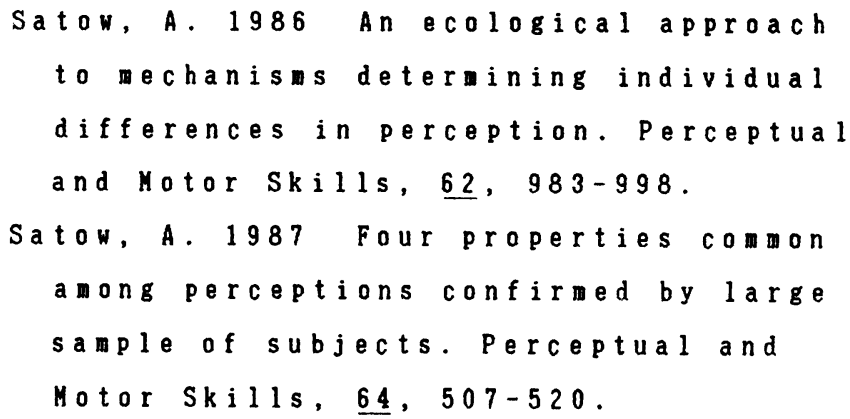

参考文献

佐藤愛子1992 感覚尺度：音の感賞尺度を中 心として。照明学会明るさ感賞の尺度化と 標準的観测者研究調查委員会報告書第 6 童 (印刷中)

佐歷要子1990 音の刺澈量と感賞量。第4 回 明るさ感賞の尺度化と標準的観測者研究調 查委員会資料資料番号 $4-1$

佐藤愛子1991 光と人間の生活：受光総量の

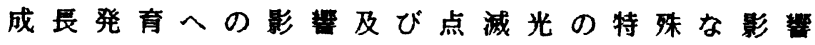
照明学会研究会資料: 光放射の応用. 関連 計測研究会編「光と人間成長発育および健 康」 A R - $91-17 \sim \begin{array}{llllll} & 1 & -1 & -1 & -17\end{array}$ ページ 